\title{
Johnsongrass mosaic virus Contributes to Maize Lethal Necrosis in East Africa
}

Lucy R. Stewart, Corn, Soybean, and Wheat Quality Research Unit, United States Department of Agriculture-Agricultural Research Service (USDA-ARS), Wooster, OH 44691; and Department of Plant Pathology, The Ohio State University, Wooster 44691; Kristen Willie, Corn, Soybean, and Wheat Quality Research Unit, USDA-ARS; Saranga Wijeratne, Molecular and Cellular Imaging Center, The Ohio State University; Margaret G. Redinbaugh, Corn, Soybean, and Wheat Quality Research Unit, USDA-ARS, and Department of Plant Pathology, The Ohio State University; Deogracious Massawe, Department of Plant Pathology, The Ohio State University; Charles L. Niblett, Venganza, Inc., St. Augustine, FL 32080; Andrew Kiggundu, National Agricultural Research Organization, Kampala, Uganda; and Theodore Asiimwe, Biotechnology Program, Rwanda Agriculture Board, Airport Road 5016, Kigali, Rwanda

\begin{abstract}
Maize lethal necrosis (MLN), a severe virus disease of maize, has emerged in East Africa in recent years with devastating effects on production and food security where maize is a staple subsistence crop. In extensive surveys of MLN-symptomatic plants in East Africa, sequences of Johnsongrass mosaic virus (JGMV) were identified in Uganda, Kenya, Rwanda, and Tanzania. The East African JGMV is distinct from previously reported isolates and infects maize, sorghum, and Johnsongrass but not wheat or oat. This isolate causes MLN in coinfection with Maize chlorotic mottle virus (MCMV), as

reported for other potyviruses, and was present in MLN-symptomatic plants in which the major East African potyvirus, Sugarcane mosaic virus (SCMV), was not detected. Virus titers were compared in single and coinfections by quantitative reverse transcription-polymerase chain reaction. MCMV titer increased in coinfected plants whereas SCMV, Maize dwarf mosaic virus, and JGMV titers were unchanged compared with single infections at 11 days postinoculation. Together, these results demonstrate the presence of an East African JGMV that contributes to MLN in the region.
\end{abstract}

Maize lethal necrosis (MLN) recently emerged as a major disease in East Africa, expanding its range from previous locations where it was a sporadic problem (Deng et al. 2014; Huang et al. 2016; Lukanda et al. 2014; Mahuku et al. 2015a,b; Niblett and Claflin 1978; Uyemoto et al. 1980; Wangai et al. 2012; Xie et al. 2011). Losses due to MLN are high in this region, where maize is a staple crop for smallholder farmers (Mahuku et al. 2015a), affecting food security. MLN is caused by coinfection of Maize chlorotic mottle virus (MCMV) and a maize-infecting virus from the family Potyviridae, including Sugarcane mosaic virus (SCMV), Maize dwarf mosaic virus (MDMV), or Wheat streak mosaic virus (WSMV)(Goldberg and Brakke 1987; Niblett and Claflin 1978; Uyemoto et al. 1980). High populations of the vectors transmitting the causal viruses are present: maize thrips (Frankliniella williamsi) for MCMV (Cabanas and Bressan 2011; Mahuku et al. 2015a) and several aphid species for the potyviruses (Louie 1980; Teakle and Grylls 1973). Maizeinfecting potyviruses are ubiquitous worldwide, with SCMV prevalent in East Africa and MDMV being the most common maize virus in the United States (Gordon et al. 1978). Synergistic coinfections of MCMV and potyviruses cause very severe virus symptoms, including chlorosis, stunting, necrosis, and premature plant death, resulting in reduced or negligible yields.

SCMV was known to be present in East Africa and Asia where MLN has emerged. Recent studies on virus populations in East Africa showed that MCMV sequences are highly conserved across the region but populations of SCMV and other potyviruses are highly diverse (Mahuku et al. 2015a). For example, RNA-Seq surveys for

Corresponding author: L. R. Stewart; E-mail: lucy.stewart@ars.usda.gov

Mention of trade names or commercial products in this publication is solely for the purpose of providing specific information and does not imply recommendation or endorsement by the U.S. Department of Agriculture.

*The $\boldsymbol{e}$-Xtra logo stands for "electronic extra" and indicates that two supplementary figures and three supplementary tables are published online.

Accepted for publication 14 April 2017.

This article is in the public domain and not copyrightable. It may be freely reprinted with customary crediting of the source. The American Phytopathological Society, 2017. viruses in maize in Kenya and Uganda identified SCMV sequences that differ by as much as $22 \%$ nucleotide sequence identity in the polyprotein coding sequence (Mahuku et al. 2015a). In addition to a diverse population of SCMV-like sequences in the East African surveyed samples, we identified other potyviruses, including one most similar to Johnsongrass mosaic virus (JGMV). JGMV has previously been reported in the United States in Texas and Kansas, as well as in Brazil, Venezuela, Australia, and Nigeria (Camelo-García et al. 2016; Garrido and Trujillo 1993; Laidlaw et al. 2004; McDaniel and Gordon 1985, 1989; McKern et al. 1990; Seifers et al. 2005; Shukla et al. 1992; Silva et al. 2013, 2016; Tosic et al. 1990). Here, we report isolation and characterization of an East African JGMV found in Kenya, Uganda, Rwanda, and Tanzania associated with MLN-diseased samples.

\section{Materials and Methods}

Sample collection, RNA-Seq, and bioinformatics. Samples were collected at 41 locations in Kenya and Uganda during 2013 to 2014 from maize and other grasses showing symptoms of MLN. Samples were collected and processed for RNA sequencing as previously indicated (Mahuku et al. 2015a). RNA-Seq of samples pooled by location each yielded approximately 18 million 100 bp paired-end reads. After subtraction of sequences mapping to maize and de novo assembly of unmapped reads, plant virus-like contigs were identified by blastn and tblastx comparisons to a custom plant virus database, as previously reported (Mahuku et al. 2015a; Stewart et al. 2014).

Enzyme-linked immunosorbent assay, strip, and reversetranscription polymerase chain reaction detection. All samples were ground in 30 volumes of extraction buffer $\left(0.02 \mathrm{M} \mathrm{NaPO}_{4}\right.$ [pH 7.4], $0.15 \mathrm{M} \mathrm{NaCl}, 0.05 \%$ Tween-20, $2 \%$ polyvinylpyrrolidone [PVP], and $0.2 \%$ bovine serum albumin [BSA]) in 4-ml grinding bags with a handheld tissue homogenizer, similar to a protocol previously described (Redinbaugh et al. 2010). Extract was used for protein-A sandwich enzyme-linked immunosorbent assays (PASELISA), as previously described (Edwards and Cooper 1985), and Potyvirus Immunostrip tests (Agdia, Inc., Elkhart, IN), according to the manufacturer's instructions. Antisera against U.S. JGMV (9016 1:400), MDMV-OH (01-A 1:2000), and SCMV-OH (905 1:400) were raised in rabbits, as described before (Lenardon et al. 1993), and used at the indicated ratios for experiments reported in Table 1. Commercial antisera (Agdia, Inc.) against MCMV, Maize streak virus (MSV), and SCMV also were used for PAS-ELISA tests 
reported in Tables 1 and 2. Plants were scored as infected if the change in ELISA absorbance at $405 \mathrm{~nm}$ was more than twice that of samples from uninoculated control plants of the same species.

In addition to serological assays, reverse-transcription polymerase chain reaction (RT-PCR) was performed to detect the JGMV East African isolate (JGMV-EA) using the protocol previously reported (Jarugula et al. 2010), except that SuperScript III (Invitrogen, Carlsbad, CA) and GoTaq (Promega Corp., Madison, WI) were used. Samples were scored as infected with JGMV-EA when there was an approximately 692-bp product from RT-PCR amplification with primers LRS670 and LRS671 (Supplementary Table S1).

Pathogen transmission and isolation. Extracts for rub inoculation were prepared from 26 lyophilized leaf tissue samples selected from Uganda and Kenya from RNA-Seq pools containing JGMVlike sequences. Samples were ground in five volumes of $10 \mathrm{mM}$ potassium phosphate, $\mathrm{pH} 7$, or 30 volumes of buffer $(137 \mathrm{mM} \mathrm{NaCl}$, $10 \mathrm{mM}$ potassium phosphate, $2.7 \mathrm{mM} \mathrm{KCl}, 2 \% \mathrm{PVP}$, and $0.2 \%$ BSA [pH 7.4]). Extracts were rubbed onto leaves of 10- to 11-dayold 'Atlas' and 'Sart' sorghum (MCMV nonhosts) between thumb and forefinger with inoculum mixed with 600 -mesh silicon carbide (carborundum). Plants were monitored for 2 weeks for development of symptoms, and leaf tissue was sampled for PAS-ELISA and RTPCR to confirm infection. JGMV-EA isolates 45 and 53 were derived from Kenyan samples 45 and 53 by serial passaging in sorghum
Table 2. Diagnostic results from maize tissue samples: Johnsongrass mosaic virus East African isolate (JGMV-EA) sequences identified by reversetranscription polymerase chain reaction (RT-PCR) and Maize chlorotic mottle virus (MCMV) and Sugarcane mosaic virus (SCMV) detected by protein-A sandwich enzyme-linked immunosorbent assays (PAS-ELISA) ${ }^{\mathrm{a}}$

\begin{tabular}{lccc}
\hline Country & $\begin{array}{c}\text { MCMV ELISA } \\
\text { positive/tested }\end{array}$ & $\begin{array}{c}\text { SCMV ELISA } \\
\text { positive/tested }^{\text {b }}\end{array}$ & $\begin{array}{c}\text { JGMV-EA } \\
\text { RT-PCR positive/total }\end{array}$ \\
\hline Kenya $^{\mathrm{d}}$ & $20 / 22$ & $11 / 22$ & $14 / 22$ \\
Uganda $^{\mathrm{d}}$ & $9 / 9$ & $8 / 9$ & $3 / 9$ \\
Tanzania $^{\mathrm{e}}$ & $4 / 8$ & $3 / 8$ & $3 / 8$ \\
Rwanda $^{\mathrm{f}}$ & $35 / 67$ & $19 / 67$ & $4 / 67$ \\
Total & $59 / 88$ & $38 / 90$ & $16 / 99$
\end{tabular}

a Data shown are from individual plant samples from Kenya and Uganda survey, not including the subset of tested samples from pools with RNA-Seq sequences of JGMV-EA detected and separate samples from Tanzania and Rwanda without RNA-Seq data.

b PAS-ELISA tests performed with MCMV and SCMV-OH antisera.

${ }^{c}$ Individual samples tested by RT-PCR with primers LRS670 and LRS671.

d Samples from sites not included in Table 1; no JGMV-like RNA-Seq contigs found in these pools, selected for maize lethal necrosis symptoms.

e Tanzanian samples collected from eight different maize lines at a naturally infected experimental plot in Babati, Manyara region.

${ }^{f}$ Rwandan samples were collected across the country but only 45 of 67 samples selected showed virus symptoms.

Table 1. Kenyan and Ugandan diagnostic test results from individual plants from the subset of pooled samples with Johnsongrass mosaic virus East African isolate (JGMV-EA) sequences identified in the RNA-Seq survey ${ }^{\mathrm{a}}$

\begin{tabular}{|c|c|c|c|c|c|c|c|c|c|c|c|c|}
\hline \multirow[b]{2}{*}{ Pool } & \multirow[b]{2}{*}{ Code } & \multirow[b]{2}{*}{ Country } & \multirow[b]{2}{*}{ Host species } & \multicolumn{2}{|c|}{ SCMV } & \multicolumn{2}{|c|}{ MDMV } & \multicolumn{3}{|c|}{ JGMV } & \multirow{2}{*}{$\frac{\text { MCMV }}{\mathrm{E}}$} & \multirow[b]{2}{*}{ Strip ${ }^{1}$} \\
\hline & & & & $\overline{\mathbf{R}^{\mathbf{b}}}$ & $\mathbf{E}$ & $\overline{\mathbf{R}^{\mathrm{c}}}$ & $\mathbf{E}$ & $\overline{\mathbf{R}^{\mathbf{d}}}$ & $\mathbf{R}^{\mathbf{e}}$ & $\mathbf{E}$ & & \\
\hline$\overline{1}$ & 152 & Kenya & Allium сера & - & - & - & + & + & + & +++ & + & + \\
\hline 2 & 17 & Uganda & Cleistachne sorghoides & NT & NT & NT & NT & NT & NT & NT & - & NT \\
\hline 3 & 34 & Uganda & Pennisetum purpureum & NT & - & NT & - & NT & NT & - & + & $-?$ \\
\hline 4 & 41 & Kenya & Sorghum bicolor & - & - & - & - & +++ & + & +++ & - & + \\
\hline 5 & 51 & Kenya & S. bicolor & - & - & - & - & +++ & + & +++ & + & $?$ \\
\hline 5 & 53 & Kenya & Tricaceae spp. & - & - & - & - & +++ & + & ++ & + & + \\
\hline 6 & 157 & Kenya & Zea mays & - & - & - & - & + & + & - & - & + \\
\hline 7 & 29 & Uganda & Z. mays & NT & - & NT & - & NT & NT & - & - & - \\
\hline 8 & 135 & Kenya & Z. mays & - & - & - & - & - & + & - & - & + \\
\hline 8 & 145 & Kenya & Z. mays & NT & - & NT & - & NT & NT & - & - & + \\
\hline 9 & 291 & Uganda & Z. mays & NT & - & NT & - & NT & NT & - & - & + \\
\hline 10 & 6 & Kenya & Z. mays & NT & +++ & NT & +++ & NT & NT & + & - & + \\
\hline 10 & 8 & Kenya & Z. mays & NT & +++ & NT & +++ & NT & NT & + & - & + \\
\hline 11 & 45 & Kenya & Z. mays & +++ & +++ & - & + & + & + & + & - & + \\
\hline 12 & 55 & Kenya & Z. mays & - & - & - & - & + & + & ++ & + & - \\
\hline 13 & 68 & Kenya & Z. mays & NT & - & NT & - & NT & + & - & + & + \\
\hline 13 & 72 & Kenya & Z. mays & - & + & - & - & ++ & + & - & + & + \\
\hline 14 & 76 & Kenya & Z. mays & - & - & - & - & + & + & - & + & + \\
\hline 14 & 79 & Kenya & Z. mays & - & - & - & - & + & + & - & + & + \\
\hline 15 & 94 & Kenya & Z. mays & - & - & - & - & + & + & - & + & + \\
\hline 16 & 104 & Kenya & Z. mays & - & - & - & - & + & + & - & + & + \\
\hline 17 & 110 & Kenya & Z. mays & - & - & - & - & + & + & - & + & + \\
\hline 18 & 116 & Kenya & Z. mays & - & - & - & - & + & + & - & + & + \\
\hline 18 & 117 & Kenya & Z. mays & - & - & - & - & + & + & - & + & + \\
\hline 18 & 118 & Kenya & Z. mays & - & - & - & - & + & + & - & + & $-?$ \\
\hline 18 & 119 & Kenya & Z. mays & - & - & - & - & + & + & - & + & + \\
\hline 28 & 285 & Uganda & Z. mays & NT & - & NT & - & NT & NT & - & + & + \\
\hline NA & Isolate 45 & Kenya & Z. mays & - & - & - & - & + & + & ++ & NT & NT \\
\hline NA & Isolate 53 & Kenya & Z. mays & - & - & - & - & + & + & ++ & NT & NT \\
\hline NA & $\mathrm{HC}$ & United States & Z. mays & - & - & - & - & - & - & - & NT & - \\
\hline NA & MDMV & United States & Z. mays & NT & - & +++ & ++ & - & NT & - & NT & +++ \\
\hline NA & SCMV & United States & Z. mays & +++ & +++ & NT & - & - & - & - & NT & + \\
\hline NA & JGMV & United States & Z. mays & - & - & NT & - & + & - & +++ & NT & + \\
\hline
\end{tabular}

a SCMV = Sugarcane mosaic virus, $\mathrm{MDMV}=$ Maize dwarf mosaic virus, and MCMV = Maize chlorotic mottle virus; $\mathrm{R}=$ reverse-transcription polymerase chain reaction and $\mathrm{E}=$ enzyme-linked immunosorbent assay. Number of plus signs is based on qualitative assessment of signal strength in assay. NT= not tested. Samples 6 to 34 were not tested due to no further available tissue for RNA isolation.

b Primers $8679 \mathrm{~F}$ and $9595 \mathrm{R}$.

c Primers $1465 \mathrm{~F}$ and $2226 \mathrm{R}$.

d Primers LRS674 and LRS675.

e Primers LRS670 and LRS671.

${ }^{\mathrm{f}}$ Generic potyvirus strip test (Agdia, Inc., Elkhart, IN). 
(Table 1). Isolates of MDMV and SCMV (formerly MDMV-B) were previously collected in Ohio and maintained by vascular puncture inoculation and mechanical transmission (Louie 1986; Stewart et al. 2012). The JGMV isolate was originally collected in the United States (McDaniel and Gordon 1985) and was similarly maintained. The U.S. MCMV isolate used in experiments originated in Kansas (Nault et al. 1978).

Host range tests. Extracts were prepared from symptomatic leaf tissue of Atlas sorghum plants inoculated with isolates 45, 53, or U.S. JGMV in five volumes of $0.01 \mathrm{M}$ potassium phosphate, $\mathrm{pH} 7$. Atlas sorghum, Sart sorghum, 'Armor' oat, 'Freedom' wheat, and 'Spirit' maize were rub inoculated 13 days postplanting and again 16 days postplanting. Plants were scored for symptoms up to 27 days postinoculation. Plants were tested via RT-PCR at 27 days postplanting or 14 days post initial inoculation (dpi) on pools (plants pooled per pot using symptomatic plants if present) of noninoculated new growth (systemic) leaves with primers testing for East African JGMV (LRS670 and LRS671), U.S. JGMV (LRS672 and LRS673), and SCMV (LRS762 and LRS763).

$5^{\prime}$ and $3^{\prime}$ Rapid amplification of cDNA ends end sequencing of isolates 45 and 53. Total RNA was extracted from leaves of infected Atlas sorghum using the Direct-zol RNA MiniPrep Plus kit (Zymo Research Corporation, Irvine, CA), according to the manufacturer's protocol. The $5^{\prime}$-end sequences were confirmed using the First Choice RLM RACE kit (Invitrogen-Thermo Fisher Scientific, Carlsbad, CA) and East African JGMV-specific primers for $5^{\prime}$ and $3^{\prime}$ rapid amplification of cDNA ends (RACE) ( $5^{\prime}$ RACE GS outer primer LRS706 GTTTGGGCTCATGTTTTGGT, 5' RACE GS inner primer LRS707 5'-ATCGAATATGCGCTGCTCTT-3', 3' RACE GS outer primer LRS708 5'-AGGAGGAGGAACAACCGTCT-3', and $3^{\prime}$ RACE GS inner primer LRS709 5'-TACCTATGGGCCTT CAGCAC-3') according to the manufacturer's instructions, except that the cDNA was amplified using PrimeSTAR HS DNA polymerase (Takara Bio, Mountain View, CA). After amplification, fragments were purified using the Zymoclean Gel DNA Recovery Kit (Zymo Research) and each purified fragment was added to a reaction mixture containing $2.5 \mathrm{mM} \mathrm{MgCl}, 0.2 \mathrm{mM}$ dATP, $5 \mathrm{U}$ of GoTaq DNA polymerase, and buffer. After a $15-\mathrm{min}$ incubation at $70^{\circ} \mathrm{C}$, each resulting A-tailed fragment was cloned into pCR4TOPO vector (Invitrogen-ThermoFisher Scientific) according to the manufacturer's instructions; clones were Sanger sequenced (Molecular and Cellular Imaging Center, Ohio Agriculture and Research Development Center, Wooster).

Single and coinfection rub inoculations. SCMV-OH, MDMVOH, JGMV (U.S. isolate), and each of the two East African JGMV isolates 45 and 53 were tested alone and in coinfections with MCMV by rub inoculation onto maize inbred line Oh28. Oh28 was planted at 5 seeds per $10-\mathrm{cm}$ pot, with 24 pots per experiment placed in a growth chamber set at $25^{\circ} \mathrm{C}$ with a photoperiod of $12 \mathrm{~h}$ of light and $12 \mathrm{~h}$ of darkness. Four replicates were performed, with 10 plants per treatment. The first three leaves were inoculated with single or 1:1 mixed virus inocula at 11 to 14 days after planting and again 3 days later. Inocula were prepared by grinding infected leaf tissue in 5 volumes of $0.01 \mathrm{M}$ potassium phosphate buffer, $\mathrm{pH} 7.0$, and delivered by rubbing with carborundum.

Plants were rated for symptoms on a 1 -to- 5 scale $(1=$ no symptoms, 2 = flecks, $3=$ mosaic, $4=$ bright yellow mosaic with some necrosis, and $5=$ dead) at 7, 9, 11, 14, and $21 \mathrm{dpi}$ (Supplementary Table S2). Height of the highest stem collar was measured at 14 and 21 dpi (Supplementary Table S3). Leaf samples from the noninoculated fourth leaf (whether symptomatic or not) were taken from one randomly selected plant in each pot per treatment at $11 \mathrm{dpi}$ for quantitative RT-PCR (RT-qPCR), flash frozen in liquid nitrogen, then stored at $-80^{\circ} \mathrm{C}$ in a freezer until RNA extraction.

RT-qPCR. Total RNA was extracted from frozen leaf tissue using the Direct-zol RNA MiniPrep Plus kit (Zymo Research Corporation). RNA was treated with DNase I from the same kit, according to the manufacturer's instructions. Total RNA $(1.0 \mu \mathrm{g})$ was used for each cDNA synthesis reaction using iScript Reverse Transcription Supermix (Bio-Rad, Hercules, CA) with oligo(dT) and random hexamer primers. qPCR was performed using SsoAdvanced Universal SYBR Green Supermix (Bio-Rad), according to the manufacturer's instructions. Primer concentrations were empirically optimized for best virus detection (data not shown) and were used at $0.50 \mu \mathrm{M}$ concentrations with 1:1.25 diluted cDNA (absolute cDNA concentrations were not measured). Two samples per treatment per experiment were used to measure virus (RNA). Each sample was analyzed in triplicate. Folylpolyglutamate synthase and membrane protein PB1A10.07c mRNA were used as internal references using previously designed primers (Manoli et al. 2012). MCMV primers were used to test each sample, and potyvirus primers were used only to test samples with respective inoculations. These primers were designed with Primer3 (Untergasser et al. 2012). The qPCR assays were done with $30 \mathrm{~s}$ of heating at $95^{\circ} \mathrm{C}$ followed by 40 cycles of $95^{\circ} \mathrm{C}$ for $10 \mathrm{~s}$ and $60^{\circ} \mathrm{C}$ for $30 \mathrm{~s}$. Melting curve analyses $\left(65\right.$ to $95^{\circ} \mathrm{C}$ at $0.5^{\circ} \mathrm{C}$ per $\left.5 \mathrm{~s}\right)$ were performed after amplification to confirm product specificity (data not shown). In each of three experiments, RNA from two leaf samples per treatment was analyzed, with three technical replicates per sample.

Transmission electron microscopy of virus particles. Symptomatic Oh28 leaves were cut into small pieces with a new razor blade in $200 \mu \mathrm{l}$ of $0.1 \mathrm{M}$ potassium phosphate buffer, $\mathrm{pH} 7.0$. Extract was incubated for $5 \mathrm{~min}$ at room temperature; then, one $25-\mu 1$ drop was placed on a 300-mesh formvar-coated copper grid and incubated at room temperature for $20 \mathrm{~min}$. After negative staining with phosphotungstic acid at $\mathrm{pH} 7.3$, samples were viewed and images taken with a Hitachi H-7500 electron microscope (Molecular and Cellular Imaging Center, Wooster, $\mathrm{OH}$ ). Virus particle size was measured using Image $\mathbf{J}$ software (National Institutes of Health, Washington, DC).

\section{Results}

Identification of JGMV in East African samples. MLNsymptomatic maize samples were collected from 14 locations in Uganda and 27 locations in Kenya and analyzed using RNA-Seq, as previously reported (Mahuku et al. 2015a). Bioinformatic analyses for virus-like contigs (Mahuku et al. 2015a; Stewart et al. 2014) identified sequences most similar to MCMV and SCMV in all location pools, with highly diverse SCMV-like sequences, as described previously (Mahuku et al. 2015a). Contigs with the closest matches to JGMV were found in 19 of 41 maize and nonmaize grass sample pools from locations 1 to 18 and 28 in Kenya and Uganda (Table 1). Each of these 19 location pools yielded RNA-Seq contigs with the closest matches to both MCMV and SCMV, in addition to JGMVlike contigs.

The 27 individual plant samples making up the 19 pools in which JGMV-like sequences were identified were further tested by PASELISA and RT-PCR for potyviruses MDMV, SCMV, and JGMV, as well as MCMV and MSV. ELISA detected viruses in fewer samples than RNA-Seq or RT-PCR did. Previously identified MSVinfected plants were excluded in plant selection for RNA-Seq, and MSV was not ELISA detected in any of these samples. Even though all samples were selected for MLN symptoms, MCMV was ELISA detected in only 17 of 27 individual plant samples representing 11 of 19 of the sample pool subset (Table 1). SCMV was detected in 4 of 26 tested individual plant samples from four pools, and MDMV was detected in 4 of 26 tested individual plant samples from three pools using our antisera against Ohio isolates (Table 1). Potyvirus was conclusively detected in 21 of 26 individual plant samples using a potyvirus strip assay (Table 1). PAS-ELISA using antisera against a U.S. JGMV isolate detected JGMV in 8 of 26 tested individual plant samples from six pools (Table 1).

Primers were designed to confirm the JGMV-like sequence based on RNA sequencing contigs. Primers LRS670 and LRS671, designed based on the RNA-Seq contigs from Kenya and Uganda, did not amplify the U.S. JGMV sequence but did amplify the East African JGMV-like virus sequence from all of the RNA-Seqpositive samples (Table 1). East African JGMV-specific primers that also amplified a sequence from the virus were also detected in 14 of 22 Kenyan and 3 of 9 Ugandan samples from the same survey but RNA-Seq contigs were not identified for them (from locations at the 41 sample sites other than 1 to 18 and 28). We also tested 
samples from other countries not included in the Kenya and Uganda RNA-Seq survey and detected the East African JGMV in 3 of 8 samples collected from Babati, Manyara region in Tanzania and 4 of 67 samples collected from locations across Rwanda (Table 2; Supplementary Fig. S1). Unlike the Kenyan, Ugandan, and Tanzanian samples selected for symptomatic natural infection, the Rwandan samples were not all selected for MLN symptoms and 22 of the 67 samples were rated as asymptomatic, including 1 sample that tested positive for JGMV-EA.

JGMV-EA isolation and characterization. Virus was transferred from two plants (isolates 45 and 53) by mechanical transmission from leaf tissue samples to Atlas sorghum (which is a nonhost for MCMV) and serial passaging on Sart sorghum (which is a nonhost for SCMV) until no SCMV or other potyviruses were detected (Table 1). Both isolates were RACE end sequenced to obtain a consensus East African JGMV sequence together with partially Sanger sequence-validated RNA-Seq contig data (JGMV-EA; GenBank accession number KX897165). JGMV-EA showed very mild mosaic symptoms on infected Spirit maize and flexuous rod-shaped virions with a modal length of $740 \mathrm{~nm}$ in transmission electron micrographs (Fig. 1; data not shown). The JGMV-EA consensus nucleotide sequence showed 79 to $84 \%$ identity to other completely sequenced JGMV isolates, and 90 to $94 \%$ polyprotein amino acid sequence identity. The polyprotein was most similar to an isolate from Australia
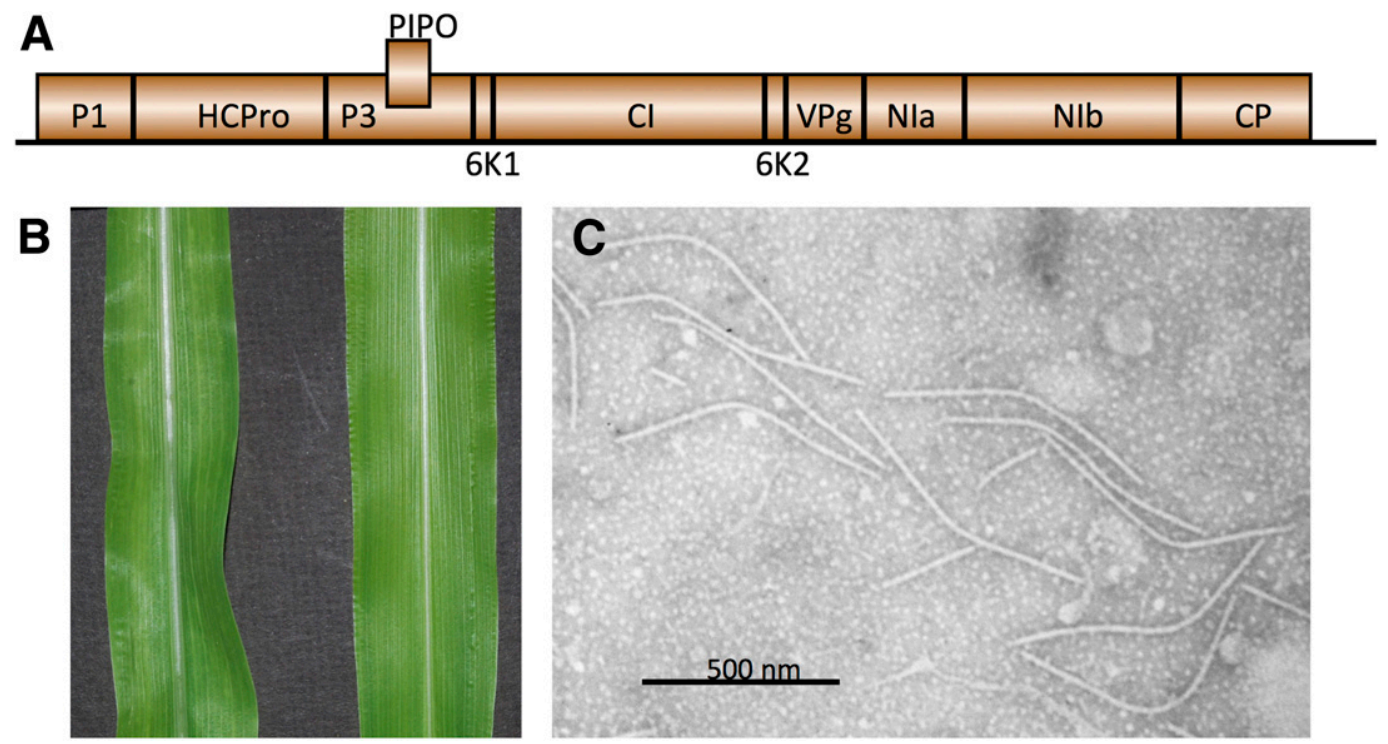

Fig. 1. Johnsongrass mosaic virus East African isolate. A, Genome map; B, symptoms (isolate 45 showing mild mosaic symptoms in Spirit maize on left, healthy control on right); and $\mathbf{C}$, transmission electron microscopy (TEM) of virions.

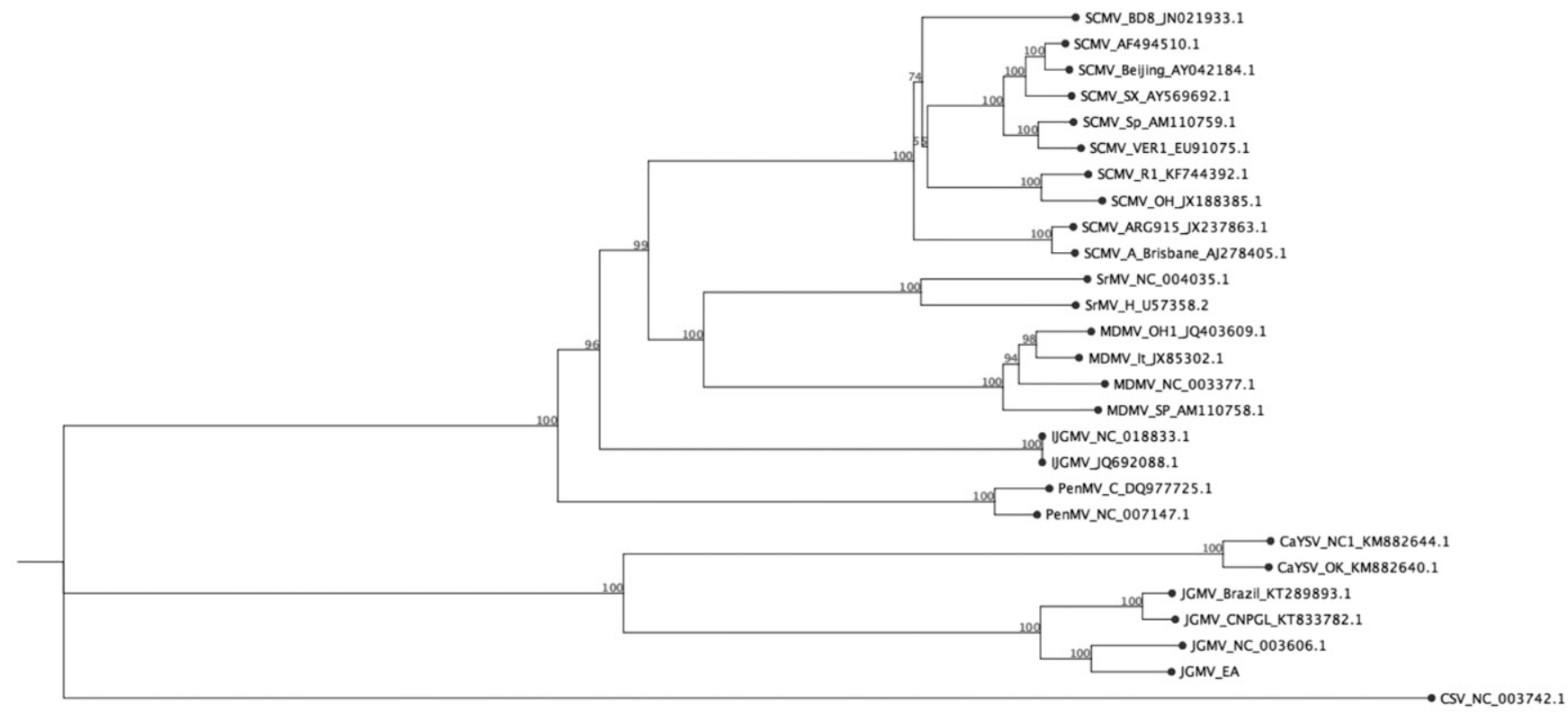

Fig. 2. Johnsongrass mosaic virus (JGMV) East African isolate (JGMV-like) polyprotein sequence neighbor-joining best tree, with maximum-likelihood phylogeny shown. Bootstrap values $(1,000)$ are indicated at nodes, with bar showing calculated genetic distance. Alignments and trees generated with CLC Genomics Workbench tools (Qiagen, Redwood City, $\mathrm{CA})$. 
Table 3. Partial host range of Kenyan Johnsongrass mosaic virus (JGMV) isolates 45 and 53 compared with a U.S. isolate of JGMV

\begin{tabular}{|c|c|c|c|c|c|c|}
\hline Isolates & Atlas sorghum & Sart sorghum & Armor oat & Freedom wheat & Spirit corn & Johnsongrass \\
\hline 45 & $35 / 39$ & $27 / 34$ & 0/many & 0/many & $18 / 20$ & + \\
\hline 53 & $43 / 68$ & $46 / 66$ & 0/many & $0 /$ many & $28 / 34$ & + \\
\hline U.S. & $61 / 74$ & $55 / 65$ & 0/many & 0/many & $11 / 15$ & - \\
\hline
\end{tabular}
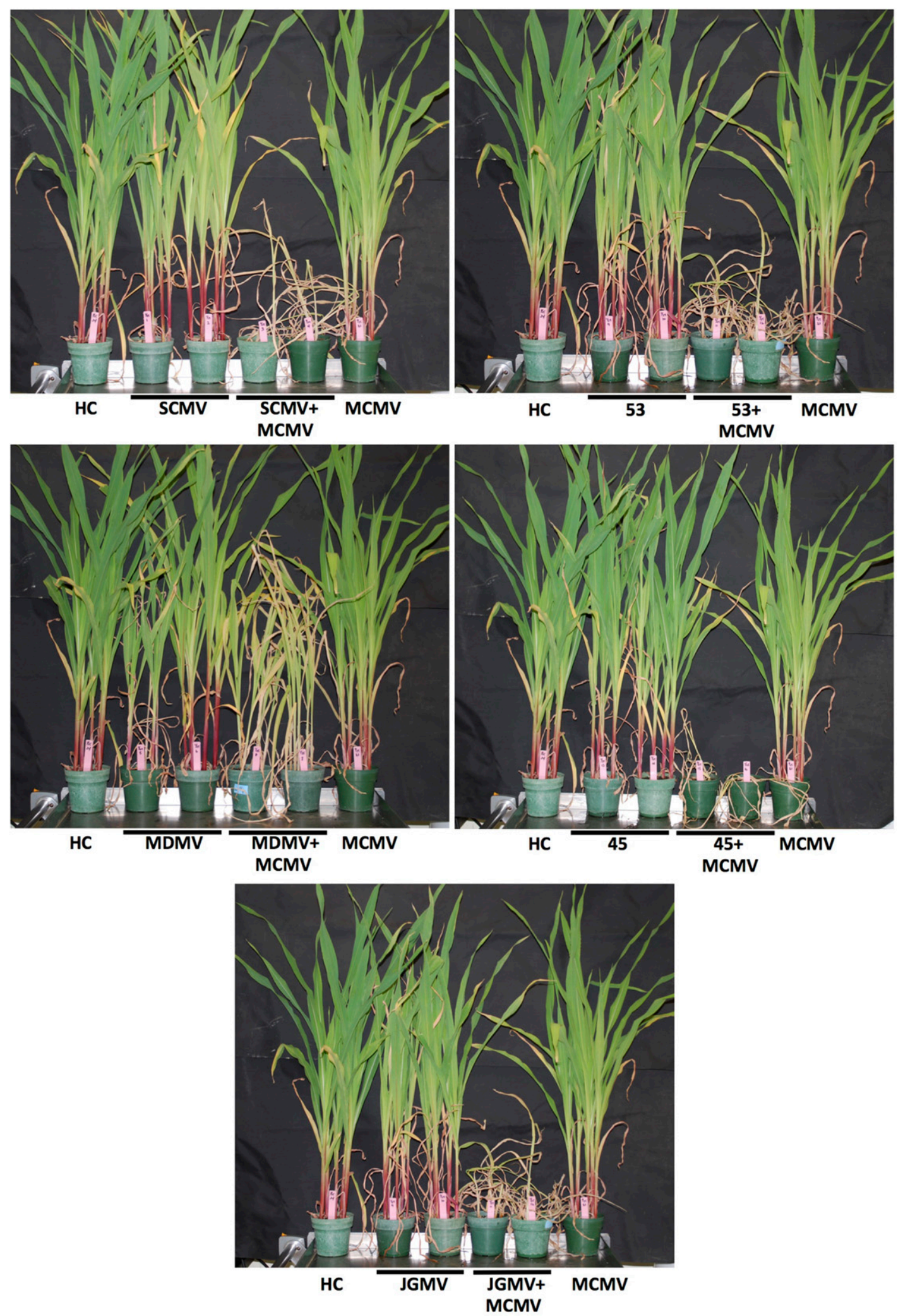

Fig. 3. East African Johnsongrass mosaic virus (JGMV) isolates 45 and 53 and U.S. JGMV cause maize lethal necrosis in combination with Maize chlorotic mottle virus (MCMV), as do other potyviruses. SCMV = Sugarcane mosaic virus and MDMV = Maize dwarf mosaic virus. Plants shown at 21 days postinoculation. 
(GenBank accession number NC_003606; Fig. 2). However, an alignment of the coat protein sequences in GenBank, mostly from Australia, indicated that JGMV-EA has an N-terminal 20-codon insertion relative to all other reported JGMV sequences, and contains other differences in the coat protein sequence that distinguish it from the previously described variability in JGMV isolates, including the Nigerian isolate (Supplementary Fig. S2). JGMV-EA infected Atlas and Sart sorghum, Spirit maize, and Johnsongrass but not Freedom wheat or Armor oat in replicated experiments (Table 3 ).

JGMV-EA virus can cause MLN in combination with MCMV. To confirm whether JGMV-EA can contribute to MLN and determine whether one or both virus titers increase in coinfections, JGMV-EA, MCMV, and coinfected plants were compared for symptom severity relative to single infections. In each experiment, JGMVEA-infected plants coinfected with MCMV showed much more severe symptoms than single infections, such that coinfected plants were dead by $21 \mathrm{dpi}$ (Fig. 3). Similar effects were produced by coinfections of MCMV and SCMV or MDMV (Fig. 3). Plant heights and disease rating scores were consistent with synergistic infection.

Previously, MLN caused by coinfection of MCMV and WSMV was shown to cause increase in titer of both of the coinfecting viruses (Scheets 1998), whereas coinfection of MCMV and MDMV resulted in increased MCMV but not MDMV titer (Goldberg and Brakke 1987). To determine how titer of each virus compared in coinfections to single infections, we conducted RT-qPCR to assess MCMV and potyvirus levels at $21 \mathrm{dpi}$. MCMV titers were normalized against MCMV single infections averaged over two biological replicates for each of four experimental replicates, with averaged MCMV levels in single infections set at 1 . Similarly, each potyvirus titer was normalized against two biological replicates of single infections with that potyvirus over each of four replicated experiments, with potyvirus titer in averaged single infections set at 1. MCMV titer in coinfected plants was extremely variable across replicates (Fig. 4A), with the highest titers in replicate 2 and lowest titers in replicate 4.
Mean MCMV titers showed a trend of higher MCMV titers in coinfections compared with single infections; however, this was only statistically validated for SCMV and the U.S. JGMV isolate and was variable across replicates, as was MCMV titer overall. Potyvirus titers measured by qPCR were less variable but still showed the highest titers for all potyviruses measured in replicate 2 and the lowest in 4 (Fig. 4B). No significant titer difference was observed between single infections and coinfections for any potyvirus.

\section{Discussion}

We describe a JGMV from East Africa and its association with the MLN outbreak there. JGMV-EA was found in Kenya, Uganda, Rwanda, and Tanzania. Although SCMV was identified as the most prevalent potyvirus in Kenyan and Ugandan samples showing MLN symptoms, JGMV-EA was present in a significant proportion of symptomatic plants, indicating that it also contributes to the disease throughout the region. JGMV was identified in samples coinfected with MCMV to cause MLN, as well as in samples in which other potyviruses were detected. This discovery, as well as the known diversity of SCMV populations associated with MLN in East Africa (Mahuku et al. 2015a), suggests that thorough or broad-spectrum potyvirus diagnostics are necessary for complete detection and containment of all the viruses contributing to MLN. Our serological data indicate that still other potyviruses such as MDMV or an MDMVlike virus are also present in a minority of MLN-diseased samples (Table 1).

Among completely sequenced isolates, JGMV-EA appears most similar to the isolate from Australia and is more distant from isolates from Brazil (Fig. 2). The coat protein is distinct from that for all other isolates for which sequence data are available, including the partially sequenced isolate previously characterized in Nigeria (Fig. 3) (Seifers et al. 2005). Apart from the Nigerian isolate, JGMV has not previously been described in Africa to our knowledge. In our experiments, JGMV-EA behaved slightly differently from the U.S.
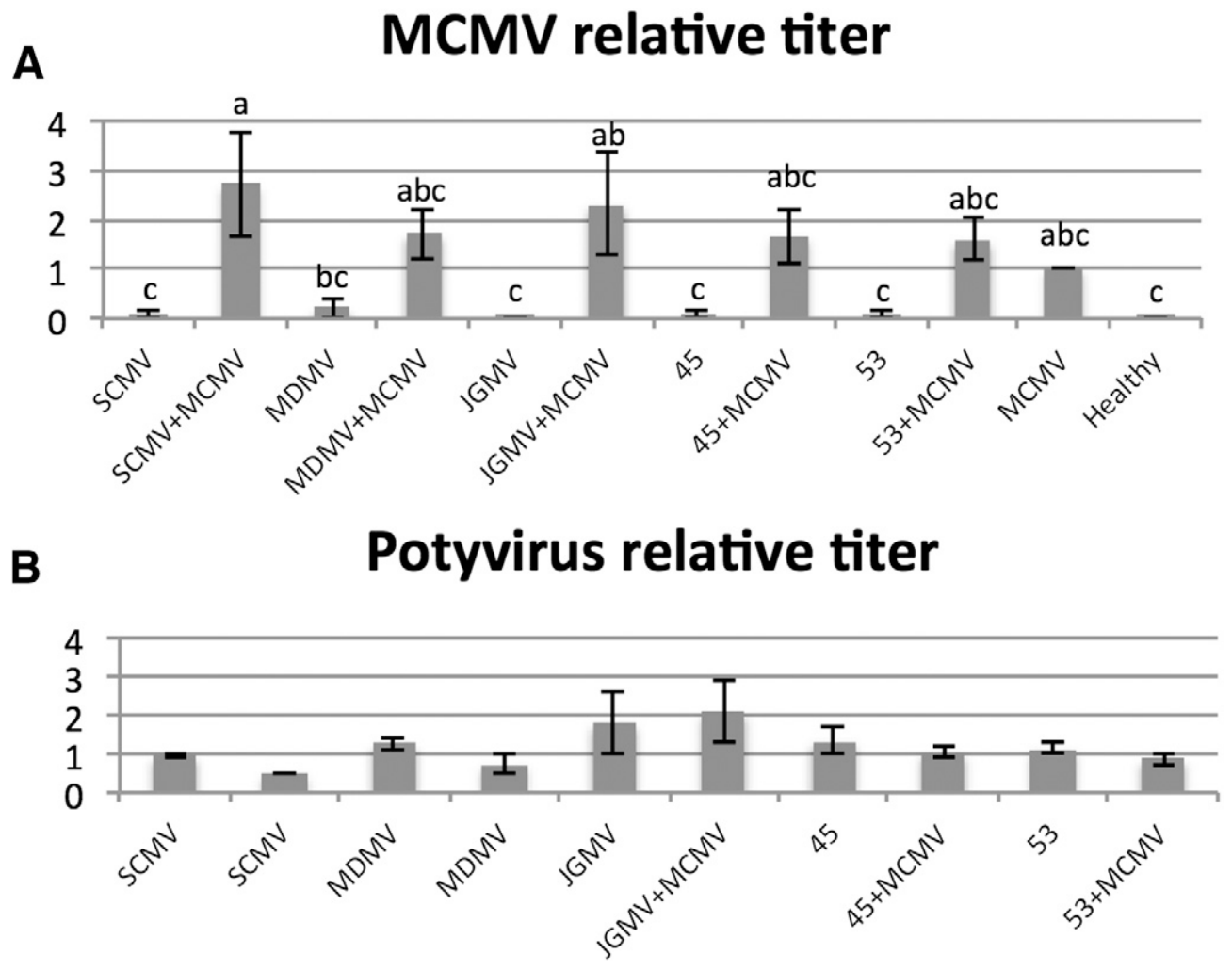

Fig. 4. Results of quantitative reverse-transcription polymerase chain reaction measuring single- and double-infection titers in four replicated experiments, with two plants tested per treatment per replicate at 11 days postinoculation. MCMV = Maize chlorotic mottle virus, SCMV = Sugarcane mosaic virus, MDMV = Maize dwarf mosaic virus, and JGMV = Johnsongrass mosaic virus. Error bars show standard error. Lowercase letters indicate analysis of variance Tukey grouping at $P=0.001$ (SAS, Cary, NC); nonoverlapping letter designations indicate statistically significant differences. Fold changes were calculated using the $\Delta \Delta \mathrm{Ct}$ method and normalized against averaged values for single infected plants in each replicate. Data shown used the folylpolyglutamate synthase housekeeping reference gene amplicon. 
JGMV isolate, with specific primers detecting only the EA isolate. JGMV-EA also infected Johnsongrass but not oat in our experiments, in contrast to our U.S. isolate and the Nigerian isolate that infected neither Johnsongrass nor oat (Table 3) (Seifers et al. 2005), despite the original description of JGMV in Texas as an oat-infecting strain of MDMV (McDaniel and Gordon 1985). JGMV is probably aphid transmitted, based on properties of related potyviruses and presence of the DAG motif in the coat protein required for aphid transmission (Atreya et al. 1990; López-Moya et al. 1999), but further experiments are needed to identify the important JGMV vector species in East Africa. Other nonmaize grasses may also be important hosts of JGMV-EA in East Africa, as suggested by our serological detection of the virus in Allium, Sorghum, and Tricaceae spp. as well as maize (Table 1), and detection by RNA-Seq in samples from other potential hosts. However, full host range and vector identification experiments of this exotic pathogen were outside the scope of this project.

In experiments to test effects of coinfection on MCMV and JGMV virus titers, we found that virus titers, especially for MCMV, were highly variable across replicates, with high variability both between replicates and between plants within each replicate. Nevertheless, on average, much higher titers were observed for MCMV in coinfections with potyviruses, consistent with previous literature comparing MCMV titer in coinfections with SCMV (previously MDMV-B) and WSMV (Goldberg and Brakke 1987; Scheets 1998), as well as the recent finding that MCMV genomic and small RNA increased in titer in SCMV coinfections (Xia et al. 2016). We found that the titer of potyviruses was slightly lower or not changed significantly in coinfections with MCMV, in contrast to the increase in titer observed for WSMV in coinfections (Scheets 1998) but consistent with the unchanged titer observed for SCMV in coinfections (Goldberg and Brakke 1987) reported previously. The different silencing suppression mechanism of WSMV (Young et al. 2012) compared with the potyviruses may play a role in the different results observed (Stenger et al. 2007). Collection time point, variable environmental conditions, and asynchronous virus movement and infection among inoculated plants may all have contributed to the variability in virus titer we observed.

In practical terms, it is apparent from our results that diversity of SCMV sequences and the presence of JGMV and, potentially, other potyviruses contributing to MLN requires broad-spectrum methods for complete detection and containment of the viruses involved in the disease. Thus, failure to identify SCMV in a sample with MLN symptoms using a single antiserum or primer pair is not an indication that no potyvirus is present. In our experiments, for example, discrepancies between RNA-Seq detection and detection by ELISA (i.e., failure to detect SCMV and MCMV serologically in samples that had contigs detected by RNA-Seq) may be a result of diverse potyvirus isolates that evade antisera and primers prepared against an Ohio SCMV isolate. Titer thresholds required for RNA-Seq, serological, and RT-PCR detection also clearly differ. Further experiments are needed to understand the individual viruses and diverse isolates associated with MLN. The presence of JGMV in East Africa contributing to MLN adds to the complexity of this virus disease problem but provides important information for developing solutions.

\section{Acknowledgments}

We thank V. Bulegeya (Ohio State University and Sokoine Agricultural University) for supplying Tanzanian samples, J. Kamatenesi (Rwanda Agricultural Board) and J. Vacha (USDA-ARS) for expert technical support, and P. Paul and J. Mera (Ohio State University) for helpful discussion and assistance in statistical analyses. This work was supported by the United States Agency for International Development (USAID)funded Innovative Agricultural Research Initiative project (iAGRI award number CA621-A-00-11-00009-00) as well as through the Bill and Melinda Gates Foundation (contract 24531 to M. G. Redinbaugh and L. R. Stewart and PEARL grant OPP1112585 to T. Asiimwe), and One Acre Fund providing support for this project.

\section{Literature Cited}

Atreya, C. D., Raccah, B., and Pirone, T. P. 1990. A point mutation in the coat protein abolishes aphid transmissibility of a potyvirus. Virology 178: $161-165$.

Cabanas, D., and Bressan, A. 2011. Dissecting the mode of transmission of Maize chlorotic mottle virus by the corn thrips, Frankliniella williamsi. (Abstr.) Phytopathology 101:S24.
Camelo-García, V. M., Andrade, S. C. D., Geering, A. D. W., Kitajima, E. W., and Rezende, J. A. M. 2016. Genome organization and host range of a Brazilian isolate of Johnsongrass mosaic virus. Arch. Virol. 161:1335-1341.

Deng, T. C., Chou, C. M., Chen, C. T., Tsai, C. H., and Lin, F. C. 2014. First report of Maize chlorotic mottle virus on sweet corn in Taiwan. Plant Dis. 98:1748.

Edwards, M. L., and Cooper, J. I. 1985. Plant-virus detection using a new form of indirect ELISA. J. Virol. Methods 11:309-319.

Garrido, M. J., and Trujillo, G. E. 1993. Occurrence of Johnsongrass mosaic virus on sorghum in Venezuela. Plant Dis. 77:847.

Goldberg, K. B., and Brakke, M. K. 1987. Concentration of maize chlorotic mottle virus increased in mixed infections with maize dwarf mosaic virus, strain B. Phytopathology 77:162-167.

Gordon, D. T., Bradfute, O. E., Gingery, R. E., Knoke, J. K., and Nault, L. R. 1978. Maize virus disease complexes in the United States: Real and potential disease problems. In: Thirty-third Annu. Corn Sorghum Res. Conf.

Huang, J., Wen, G. S., Li, M. J., Sun, C. C., Sun, Y., Zhao, M. F., and He, Y. Q 2016. First report of Maize chlorotic mottle virus naturally infecting sorghum and coix seed in China. Plant Dis. 100:1955.

Jarugula, S., Alabi, O. J., Martin, R. R., and Naidu, R. A. 2010. Genetic variability of natural populations of Grapevine leafroll-associated virus 2 in Pacific Northwest vineyards. Phytopathology 100:698-707.

Laidlaw, H. K. C., Persley, D. M., Pallaghy, C. K., and Godwin, I. D. 2004. Sequence diversity in the coat protein coding region of the genome RNA of Johnsongrass mosaic virus in Australia. Arch. Virol. 149:1633-1641.

Lenardon, S. L., Gordon, D. T., and Gingery, R. E. 1993. Serological differentiation of maize dwarf mosaic potyvirus strain a, strain $\mathrm{D}$, strain $\mathrm{E}$, and strain F by electro-blot immunoassay. Phytopathology 83:86-91.

López-Moya, J. J., Wang, R. Y., and Pirone, T. P. 1999. Context of the coat protein DAG motif affects potyvirus transmissibility by aphids. J. Gen. Virol. 80: 3281-3288.

Louie, R. 1980. Sugarcane mosaic virus in Kenya. Plant Dis. 64:944-947.

Louie, R. 1986. Effects of genotype and inoculation protocols on resistance evaluation of maize to maize dwarf mosaic virus strains. Phytopathology 76: 769-773.

Lukanda, M., Owati, A., Ogunsanya, P., Valimunzigha, K., Katsongo, K., Ndemere, H., and Kumar, P. L. 2014. First report of Maize chlorotic mottle virus infecting maize in the Democratic Republic of the Congo. Plant Dis. 98:1448.

Mahuku, G., Lockhart, B. E., Wanjala, B., Jones, M. W., Kimunye, J. N., Stewart, L. R., Cassone, B. J., Sevgan, S., Nyasani, J. O., Kusia, E., Kumar, P. L., Niblett, C. L., Kiggundu, A., Asea, G., Pappu, H. R., Wangai, A., Prasanna, B. M., and Redinbaugh, M. G. 2015a. Maize lethal necrosis (MLN), an emerging threat to maize-based food security in sub-Saharan Africa. Phytopathology 105:956-965.

Mahuku, G., Wangai, A., Sadessa, K., Teklewold, A., Wegary, D., Ayalneh, D., Adams, I., Smith, J., Bottomley, E., Bryce, S., Braidwood, L., Feyissa, B., Regassa, B., Wanjala, B., Kimunye, J. N., Mugambi, C., Monjero, K., and Prasanna, B. M. 2015b. First report of Maize chlorotic mottle virus and maize lethal necrosis on maize in Ethiopia. Plant Dis. 99:1870.

Manoli, A., Sturaro, A., Trevisan, S., Quaggiotti, S., and Nonis, A. 2012. Evaluation of candidate reference genes for qPCR in maize. J. Plant Physiol. 169:807-815.

McDaniel, L. L., and Gordon, D. T. 1985. Identification of a new strain of maize dwarf mosaic virus. Plant Dis. 69:602-607.

McDaniel, L. L., and Gordon, D. T. 1989. Characterization of the oat-infecting strain of maize dwarf mosaic virus. Phytopathology 79:113-120.

McKern, N. M., Whittaker, L. A., Strike, P. M., Ford, R. E., Jensen, S. G., and Shukla, D. D. 1990. Coat protein properties indicate that Maize dwarf mosaic virus-KS1 is a strain of Johnsongrass mosaic virus. Phytopathology 80: 907-912.

Nault, L. R., Styer, W. E., Coffey, M. E., Gordon, D. T., Negi, L. S., and Niblett, C. L. 1978. Transmission of maize chlorotic mottle virus by chrysomelid beetles. Phytopathology 68:1071-1074.

Niblett, C. L., and Claflin, L. E. 1978. Corn lethal necrosis-New virus disease of corn in Kansas. Plant Dis Rep 62:15-19.

Redinbaugh, M. G., Molineros, J. E., Vacha, J., Berry, S. A., Hammond, R. B., Madden, L. V., and Dorrance, A. E. 2010. Bean pod mottle virus spread in insect-feeding-resistant soybean. Plant Dis. 94:265-270.

Scheets, K. 1998. Maize chlorotic mottle machlomovirus and Wheat streak mosaic rymovirus concentrations increase in the synergistic disease corn lethal necrosis. Virology 242:28-38.

Seifers, D. L., Haber, S., Ens, W., She, Y. M., Standing, K. G., and Salomon, R. 2005. Characterization of a distinct Johnsongrass mosaic virus strain isolated from sorghum in Nigeria. Arch. Virol. 150:557-576.

Shukla, D. D., Frenkel, M. J., McKern, N. M., Ward, C. W., Jilka, J., Tosic, M., and Ford, R. E. 1992. Present status of the sugarcane mosaic subgroup of potyviruses. Pages 363-373 in: Potyvirus Taxonomy. Archives of Virology, Vol. 5. O. W. Barnett, Jr., ed. Springer, Vienna.

Silva, K. N., Melo, F. L., Orilio, A. F., Nagata, T., Silva, M. S., Fernandes, C. D., Fragoso, R. R., Dessaune, S. N., and Resende, R. O. 2016. Biological and molecular characterization of a highly divergent Johnsongrass mosaic virus isolate from Pennisetum purpureum. Arch. Virol. 161:1981-1986. 
Silva, K. N., Nicolini, C., Silva, M. S., Fernandes, C. D., Nagata, T., and Resende, R. O. 2013. First report of Johnsongrass mosaic virus (JGMV) Infecting Pennisetum purpureum in Brazil. Plant Dis. 97:1003.

Stenger, D. C., Young, B. A., Qu, F., Morris, T. J., and French, R. 2007. Wheat streak mosaic virus lacking helper component-proteinase is competent to produce disease synergism in double infections with Maize chlorotic mottle virus. Phytopathology 97:1213-1221.

Stewart, L. R., Bouchard, R., Redinbaugh, M. G., and Meulia, T. 2012. Complete sequence and development of a full-length infectious clone of an Ohio isolate of Maize dwarf mosaic virus (MDMV). Virus Res. 165:219-224.

Stewart, L. R., Teplier, R., Todd, J. C., Jones, M. W., Cassone, B. J., Wijeratne, S., Wijeratne, A., and Redinbaugh, M. G. 2014. Viruses in maize and Johnsongrass in southern Ohio. Phytopathology 104:1360-1369.

Teakle, D. S., and Grylls, N. E. 1973. Four strains of sugar cane mosaic virus infecting cereals and other grasses in Australia. Aust. J. Agric. Res. 24: 465-477.

Tosic, M., Ford, R. E., Shukla, D. D., and Jilka, J. 1990. Differentiation of sugarcane, maize dwarf, Johnsongrass, and sorghum mosaic viruses based on reactions of oat and some sorghum cultivars. Plant Dis. 74:549-552.
Untergasser, A., Cutcutache, I., Koressaar, T., Ye, J., Faircloth, B. C., Remm, M. and Rozen, S. G. 2012. Primer3-New capabilities and interfaces. Nucleic Acids Res. 40:e115.

Uyemoto, J. K., Bockelman, D. L., and Claflin, L. E. 1980. Severe outbreak of corn lethal necrosis disease in Kansas. Plant Dis. 64:99-100.

Wangai, A. W., Redinbaugh, M. G., Kinyua, Z. M., Miano, D. W., Leley, P. K., Kasina, M., Mahuku, G., Scheets, K., and Jeffers, D. 2012. First report of Maize chlorotic mottle virus and maize lethal necrosis in Kenya. Plant Dis. 96:1582.

Xia, Z., Zhao, Z. X., Chen, L., Li, M. J., Zhou, T., Deng, C. L., Zhou, Q., and Fan, Z. F. 2016. Synergistic infection of two viruses MCMV and SCMV increases the accumulations of both MCMV and MCMV-derived siRNAs in maize. Sci. Rep. 6: Article 20520. doi:10.1038/srep20520

Xie, L., Zhang, J. Z., Wang, Q. A., Meng, C. M., Hong, J. A., and Zhou, X. P. 2011. Characterization of Maize chlorotic mottle virus associated with maize lethal necrosis disease in China. J. Phytopathol. 159:191-193.

Young, B. A., Stenger, D. C., Qu, F., Morris, T. J., Tatineni, S., and French, R. 2012. Tritimovirus P1 functions as a suppressor of RNA silencing and an enhancer of disease symptoms. Virus Res. 163:672-677. 